\title{
Do Our Perceptions of Students' Activity Preferences Come True?
}

\author{
Hossein Saadabadi M. \\ Department of English, Bushehr Branch, \\ Islamic Azad University, Bushehr, Iran \\ E-mail: saadabadimh@gmail.com
}

Received: 14-04-2013

Accepted: 22-05-2013

Published: 01-07-2013

doi:10.7575/aiac.ijalel.v.2n.4p.174

\begin{abstract}
In order to have an effective second language education, students, and teachers should share beliefs and assumptions about language and learning as well as educational goals. Achieving such efficiency requires deep understanding of students' and teachers' beliefs, and considering them in the process of syllabus design and materials preparation for English courses. To provide a deeper understanding of Iranian university students' preferences regarding activities in General English classes, this research tried to find the participants' preferences and expectations in foreign language learning and teaching through finding out whether there is any correspondence between teachers' and learners' preferred activities, and to what extent teachers' beliefs about language learning and class activities correspond with those of the learners'. To obtain the required data, this study made use of a questionnaire that covered areas such as language skills, feedback, testing and evaluation, participation mode, and class size. statistical analysis of the data (Independent samples t-test) showed that only $43.75 \%$; namely, twenty one out of forty eight of the differences were significant at 0.05 or below. These findings indicate a need to take more time to share ideas with students regarding classroom practices.
\end{abstract}

Keywords: Second language education, Needs analysis, Learners's belief, Teachers' belief

\section{Background}

Over the years, upon each exam, my students have complained that they are facing challenges predicting the test items. They said that what they had guessed as important and worked upon had been far away from the test items they had encountered on the paper. Although this was not true for all other colleagues, we all shared the same problem in the course 'General English' henceforth named (GE). GE is a 3 credit course which all university students (non-English majors) have to pass prior to their ESP. This course is naturally devoted to reading and vocabulary improvement and grammar practice. The medium of the class is the students' native language (Persian), and teachers mostly employ a sort of Grammar Translation Method.

The way university students respond to these classes, the way they attend the classes, and the outcomes, all show that despite the facilities, time and funds, the outcome is quite disappointing, and students show no interest in the course (Noora, 2008). The evidence for this dissatisfaction is that the students show little interest in attending these classes; furthermore, the students attending the following ESP courses, lack the minimum requirements for the course, and the instructors teaching GE courses most often find the class boring and rather frustrating.

This failure is due to many factors the most disappointing of which is syllabus implementation (textbooks used, hours of practice, teachers' efficacy, etc.), the content of the syllabus, learners' aptitude and attitude towards attending GE classes, and finally the extent of GE instructors 'belief in the significance of the course. Toussi (1998) counts 8 difficulties which he considers are unique to the Iranian setting and are the source of suffer for the Iranian ELT situation. Among all he includes a) "Paying no attention to learner related factors", b) "Learners' little or no understanding of aims" and c) "Low motivation and rather negative attitude towards a language and its use" (p. 22)

\subsection{Learner-centred Approach}

The problems mentioned above, are mainly rooted in the unidirectional top-down nature of the Iranian GE curriculum. In this system, a group of experts in the capital decides and designs a curriculum and a syllabus for the whole nation, and learner, teacher and context variations are not at all considered. This is while, in an educational context as diverse as Iran, for a curriculum to be successful, a learner-centred approach is inevitable.

A learner-centred curriculum is, by definition, a collaborative effort between teachers and learners. In this approach, learners are closely involved in the process of making decisions regarding the content of the curriculum as well as the way it is taught (Nunan, 1988). However, the extent to which it is possible or desirable for learners to be involved in their own learning differs from learner to learner and from context to context.

Nunan (1999) is in the same line with Toussi (1998) and emphasizes attending to learners' needs and their educational goals. In fact, with the emergence of humanistic and cognitive psychology, learners are invited to play active roles in 
classroom and take more responsibilities (Gabillon, 2005). Such learners learn from their own experiences, make their own choices, and respond to events, as they perceive them(Meskill \& Rangelova, 2000; Savage \& Storer, 1992).

The success or failure a learner-centred approach largely depends on good awareness of learners' needs. (Peacock, 1997) also shows concerns about ignoring the role of learners in ELT syllabus design. He tries to find correlations between teacher and learner view on the usefulness and enjoyableness of teaching materials.

Since GE was a prerequisite to ESP, all GE students shared the same needs. However, due to their educational, social and economic background, these students had different perceptions of aspects of language including language learning and language teaching as well as the role of learner and teacher. These perceptions are important because they can affect students' motivation, attitude and learning strategies (Richards \& Schmidt, 2002).

This research was an attempt to analyse GE students' needs and to figure out to what extent GE instructors covered students' priorities in their syllabuses.

\subsection{Objectives of the study}

This research considers the content of the GE syllabus as one serious source of the program breakdown. This choice is the result of a feel that the learners do not exactly learn what teachers teach; in fact, learners seem to focus on something else. That is to say, between teachers' pedagogical intentions, and the knowledge that the learners take away from instructional activities, there is a gap (Nunan, 1995).

Practically, this research aims to find, through needs analysis, the participants' preferences and expectations in foreign language learning and teaching, and hence, find a way out of the current wasteland. To this end, this research needs to answer the following questions:

1. Is there any correspondence between teachers' and learners' preferred activities?

2. To what extent teachers' beliefs about language learning and class activities correspond with those of the learners'?

\subsection{Significance of the study}

General English (GE) is a 3-credit course, which any university student (non-majoring English) should pass. This course aims at preparing university students for ESP courses they study in later semesters.

For years, GE teachers have been teaching this course just to teach it. Neither the goal pre-determined in the course syllabus, nor any other goal defined by teachers themselves has been considered. In fact, during this course, teachers try their best to teach students what they think a GE student should learn as FL.

Another deficiency in leading to the present situation in Iran is the methodology or lack of methodology in teaching English in schools and later in GE courses so far.

Teaching GE in Iranian universities in based on a syllabus developed by the government officials and followed nationally. Findings of this research can help GE curriculum developers and policy makers to consider the learners' educational goals and their cultural and emotional needs while developing the syllabus. On the other hand, these findings can also arm FL teachers with a knowledge through which they can negotiate with the learners in order to set and moderate their beliefs about language and language learning. Teachers can also use these findings to train their students to find and use their own learning strategies in and outside the classroom individually.

\section{Review of literature}

The story behind the topic dates back to the 1980 s when Allwright (1984) so admirably raised a question. He asked: "why don't learners learn what teachers teach?" This is a story told repeatedly by Nunan to explain how he got interested to study the subject (e.g.Nunan, 1995, 1999).

Nunan (1995) investigates the mismatch between the pedagogical intentions and plan of the method and their outcome, and explores the sources of mismatch in three main domains: a) the experiential content domain where he finds the reasons for this disparity in a "mismatch between the pedagogical agenda of the teacher and that of the learner" (p. 135); b) the learning process domain where he claims that a partial answer to the question can be found at the level of learning process. He further explains that learners are not familiar with the learning strategies behind each task, and are not trained and encouraged to use such strategies. Also learners do not enjoy the chance to contribute to the learning process through making choices and selecting alternative tasks. C) the language contact domain: a minor reason for the mismatch, according to Nunan (1995), lies in the doubt in the relationship between language forms and their communicative functions. In other words, teachers are not still sure enough whether providing students with opportunities to interact is adequate, or students need explicit instruction, or even a combination of the two.

Following Nunan (1995), further elaborated in Nunan (1999) in support of the concept of learner-centeredness, Spratt (1999) empirically tried to "examine the degree of correspondence between learners' preferred activities and the activities teacher believed the learners liked"(p. 142).

Using a sample of 997 students and 50 teachers of English department, Spratt (1999) obtains the required data from a forty eight-item questionnaire and "shows clearly that the correspondence between teachers and learners was only about $50 \%$ and that this correspondence (or lack of it) was true for all types and areas of activities". In her later article, (Spratt, 2001)), she continues her investigation to explore 1) "the types of language learning activities the students preferred" and 2) "what variation there might be in student activity preferences between a)years of study and b) level of study. The new study, she believes, shows us several things about her students (Spratt, 2001, p. 97) that their preferences for 
activities are often not accurately perceived by their teachers, that they present a distinctive profile from those learning in other contexts, that they like both communicative and non-communicative activities that their preferences vary between activity areas though not greatly between years of study that they distinguish between activities that contain similarities that they favour oral skills, feedback and working with a small number of others. Many others have also posed ideas about the topic focusing on the conflicting beliefs and perceptions available among language learners and language teachers regarding what should happen in the classroom (Davies, 2006; Eslami-Rasekh \& Valizadeh, 2004; Green, 1993; Hawkey, 2006; Nation \& Macalister, 2010; Peacock, 1997, 1998, 1999; Riley, 2009; Yang, 1999).

These differences have their roots in the beliefs of the teachers and learners about foreign language teaching and learning. According to Riley (2009): "Learners bring with them into the language learning classroom a complex set of variables based on attitudes, experiences and expectations. A subset of these variables forms the beliefs which learners process about the nature of the language learning task." (p. 102). He also thinks that Students beliefs can also be influenced by teachers' beliefs, and therefore, suggests "it is necessary to also consider the beliefs of the language teachers." (p. 103). This influence, he suggests, can result from teachers explicit expression of beliefs, or implicitly, through classroom activities as well as the methodology employed by the teacher (Riley, 2009, p. 103).

In addition, describing the current situation, Kehrwald (2007) reports a number of studies related to the topic and points out that today, the ELT situation shows a change, and this can be seen in attempts to access the voices of learners, and appreciating the valuable contributions of learners to planning, developing, implementing and evaluating language teaching and learning. The consequence of this is the increased attention of the beliefs which learners bring with them to the language classroom. These beliefs about language and language learning are strongly related to learners' use of learning strategies (Yang, 1999). Although the literature certifies the mismatch under discussion, the study carried out by (Eslami-Rasekh \& Valizadeh, 2004) showed that the ELT situation in Iran is different from that of other communities in that Iranian students are more likely to use communicative activities while their teachers, not being aware of their preferences, show more tendencies to traditional approaches and strategies.

\subsection{The Iranian Context}

Needs analysis and attending to learner needs in learning a foreign language are basics of a learner-centred, communicative curriculum. Although there is a considerable body of research on language learners' needs analysis, this topic has had no place in the structural, teacher oriented context of Iranian EFL so far. Therefore, in this context, most researchers have tried, and are still trying, to improve the current situation by studying and researching the current topics. The following paragraphs review the few studies that tried to investigate the topic in recent years.

Shahini and Daftarifard (2011) studied Iranian EFL learners' beliefs of an effective L2 teacher using a 31 item questionnaire and a sample of 51 EFL students. They analysed students' beliefs about three aspects of an EFL teacher; namely, personality, proficiency and teaching skills. They concluded that, in students' view, teachers' ability to teaching techniques is the teachers' most important characteristics. Other factors they report are in turn teachers 'proficiency' and 'knowledge transmission'. These characteristics are then followed by teachers' personal behaviour towards students.

Another study on the topic is (Noora, 2008). This research investigated non-English major EFL students' preferences about learning English, and found significant differences among non-English majors' preferences. In his study, he collects data through a 13 item questionnaire and a sample of 193 students from different fields. This study reports that $58.6 \%$ of students in social sciences like to be able to read in English while only $4.8 \%$ of students of physics hold this belief. This research concludes that reading is not the ultimate goal of learning English, and most of the participants prefer to learn English for communication.

Based on the findings of his research, Noora (2008) also claims that a majority of the participants were not interested in college English while they had positive attitudes to language learning in general, and that they were highly motivated to learn English for communication. This claim was previously proved by Eslami-Rasekh and Valizadeh (2004)which had studied the degree of discrepancy between learners preferences and instructors awareness of those preferences in the Iranian GE context. This discrepancy is what instructors and syllabus designers are not aware or do not care about.

Eslami-Rasekh and Valizadeh (2004) is the only study that directly deals with the topic. This study investigates classroom activities from both teachers, and learners' perspectives. However, this research has some deficiencies that have determinant effect on the outcomes. In this study, for instance, the researchers do not describe the sample fully. Also, it is not identified in the research that the participants have been from all parts of the country or just a certain region. Iran is a wide country that covers a population diverse both in culture and first language. Such a diverse population has different needs regarding their foreign language learning, and this diversity should be considered in any needs assessment project in Iran. Therefore, to study such an EFL context, the population sample as well as the setting of the research should be described in details.

This study was conducted to broaden the scope of studies done on the topic and shed more light on students' and instructors' perceptions of instructional activities. The present study included learners of GE from universities in southwest provinces of Iran with a different sociocultural context from other parts of the country. 


\section{Methodology}

\subsection{Participants}

Two groups of participants took part in this research. One group included 28 teachers from 5 different universities who filled up the questionnaire completely. These teachers had a master degree in teaching English as a foreign language or English literature. Although they has the experience of teaching English in different levels and different situations, regarding teaching university general English course, 12 teachers had more than two years of experience, 10 teachers more than 5 years and 6 teachers more than 10 years of experience. In addition, 10 teachers were academic staffs at their universities and 18 others were visiting teachers.

The second group of the participants included 366 students from seven universities. This sample consisted of 148 females and 218 males. Although a number of the participants had not included their age, most of the students who had mentioned their ages were between 18-25. However, there were older students in these classes. Table 3.1 describes the detailed information about the students' age.

Table 3.1. Detailed information about the students' age

\begin{tabular}{llll}
\hline Students' age & & & \\
\hline $18-20$ & $21-25$ & $26-30$ & $31-$ over \\
\hline 68 & 63 & 21 & 25 \\
\hline
\end{tabular}

Among these students, 127 had participated English classes outside university at language institutes, but the other 239 had not attended such classes. These students were from different levels and different fields of study. Table 3.2 summarizes the educational status of the participants:

Table 3. 2. Educational status of the participants

\begin{tabular}{llll}
\hline \multicolumn{4}{l}{ Educational level } \\
\hline Freshman & Sophomore & Junior & Senior \\
\hline 302 & 32 & 18 & 14 \\
\hline
\end{tabular}

\begin{tabular}{lll}
\hline \multicolumn{3}{c}{ Field of study } \\
\hline Humanities & Natural Resources & Engineering \\
\hline 190 & 21 & 155 \\
\hline
\end{tabular}

These students had different views regarding the relationship between knowledge of English and their professional and educational success.

While different participants claimed varying degrees of impact for knowledge of language in their profession, 39.34\% claimed that it has a very strong effect and $28.7 \%$ believed that English had no effect on their professional success. In addition, a majority of the students belied that speaking $(n=109)$ and Reading $(n=108)$ are more influential than writing $(n=52)$ and listening $(n=97)$. Table 3.3 reports the detailed students' beliefs about the role of English and the importance of language skills in their professional success.

Table 3.3. The role of English in students' professional success

\begin{tabular}{llll}
\hline \multicolumn{3}{l}{ Skills that influence professional success } \\
\hline Listening & Speaking & Reading & Writing \\
\hline 97 & 109 & 108 & 52 \\
\hline
\end{tabular}

\begin{tabular}{lllllll}
\hline \multicolumn{7}{l}{ English affects professional success } \\
\hline No & \multicolumn{1}{l}{ Yes } \\
\hline \multirow{2}{*}{105} & 1 & 2 & 3 & 4 & 5 & 6 \\
\cline { 2 - 7 } & 27 & 21 & 25 & 28 & 16 & 144 \\
\hline
\end{tabular}

In this table, number six is an indicator for a very strong effect and number one indicates a very poor effect.

In terms of the role of English in students' educational success, participants of this study had also different views. While $41.2 \%$ of the participants say that English plays no role in their educational success, a good number of others (33.34\%) believe that English strongly affects their educational success; however, this group considers different levels of importance for language skills. Most of the students $(n=130)$ believe that reading is the most effective language skill but other students have their own views. The second place among language skills goes to speaking ( $\mathrm{n}=95)$, and listening $(n=81)$ and writing $(n=60)$ come next. Table 3.4 summarizes the students' beliefs about the role of English and the importance of language skills in their educational success.

Table 3.4. The role of English in students' educational success

\begin{tabular}{|c|c|c|c|c|c|c|c|c|c|c|}
\hline \multicolumn{4}{|c|}{ Skills that influence educational success } & \multicolumn{7}{|c|}{ English affects educational success } \\
\hline Listening & Speaking & Reading & Writing & No & $\mathrm{Ye}$ & & & & & \\
\hline \multirow[t]{2}{*}{81} & 95 & 130 & 60 & 151 & 1 & 2 & 3 & 4 & 5 & 6 \\
\hline & & & & & 20 & 13 & 23 & 24 & 13 & 122 \\
\hline
\end{tabular}


In this table, number six indicates a very strong and number one indicates a very poor effect.

Finally, since a number of students had not fully completed the questionnare, only questionnares that were fully complted were considered for the study $(\mathrm{N}=261)$, and the others were discarded.

\subsection{Instrument}

To obtain the required data, this study used a questionnaire in order to access the opinions of a large and potentially diverse population. The questionnaire used in this study was the one used in Spratt (1999). The questionnaire was translated into Persian to make fit for the context, and then adopted based on the needs of the target audience. The questionnaire was prepared in two versions, one for students and the other for teachers. Both versions contained 48 items and used a Likert scale.

The questionnaire covered all classroom activities that teachers might ask learners to do in or outside the classroom as well as feedback, testing, and modes of participation. These are the activities, ideas and techniques usually presented and discussed in language teaching methodology books but most of them are not practiced in actual EFL classes in Iran. An interview with many teachers and learners showed that they believe that these activities should be added to the EFL curriculum. Therefore the content of the questionnaire does not reflect the actual classroom setting in the Iranian EFL context.

\subsection{Data collection}

The student questionnaire was administered at the students' final exam session. It was distributed and collected by examination staffs before the students receive their test booklets.

The teachers' questionnaire was exactly the same as the student questionnaire. The only difference was that the students' questionnaire included a section eliciting students' personal details that the teachers' version lacked. Teachers had the chance to complete the questionnaires at their free time.

In addition to the questionnaire data, in some cases, in order to have a deeper understanding of the phenomena, some participants were interviewed.

\section{Results And Discussion}

The data obtained through questionnaire were keyed in SPSS software and then analysed. The items were then categorized into five areas:language skills, feedback, testing and evaluation, participation mode, and class size.

\subsection{Language skills}

The first area that was studied in this research was language skills. Totally, 15 items of the questionnaire covered issues related to language skills including listening, speaking, reading and writing. As far as the results indicate, students have scored higher $(\mathrm{M}=4.51)$, than their teachers $(\mathrm{M}=3.66)$ regarding language skills.

Statistical analysis (independent samples t-test) of the results prove that this difference in the general attitude towards approaches to language skills is quite significant.

It means that in many cases teachers do not know about students likes and preferences regarding language skills. A closer look at the details in the questionnaire can be helpful.

Regarding reading skills, students and teachers think almost the same. The only exception in this area is including grammar in reading tasks which students like but teachers are not so willing to do. Interview with some of the participants showed that teachers prefere to teach grammar separately as an independent lesson, but students prefered to study grammar as a part of reading task because they thaught grammar can help them understand the text better.

Listening and speaking skills included more divergent items. Among five items related to listening skills, in three items students and teachers showed significantly different views. According to the results, while students prefere to listen to each other or to other students' presentations, teachers think that it is better for students to the teacher or to audio-recordings. This is, however, the task that students like, but it is not their favorite and initial demand. The same is true for speaking skills. While students prefere to talk and interact with their classmates, teachers prefered teachercentered oral exercises. Interview with students indicate that students prefer to interact with each other, talk and give feedback for each other's works without teachers' constant monitoring and interuptions for correction and feedback. Teachers, on the other hand, say that they need to evaluate students' attempts and progress, and thus they need to monitor the class more effectively, and give feedback on every individual utterance. Students, however, think that this teacher-centered, authoritative method is stressful.

Writing skill was quite a different story in which there is no correspondance between students' and teachers' preferences. In this case, statistical analysis provides evidence for the fact that there there is a significant difference between what students prefered, and what teachers did. That is to say, while students were willing to writing tasks, especially weiting short passages in their free time outside the classroom, teachers limit them to sentence level classroom exercises.

\subsection{Feedback}

Another area that was studied in this research was feedback. Regarding feedback, teachers and students have closer beliefs and preferences. According to table 4.3, students, as well as their teachers, prefer peer correction on their own works. In this case, no matter whether the feedback is oral or written, or whether it is given in the form of a class 
discussion or by individuals, feed backs are prefered to be to the point and on every individual student's work. In this case, there was significant difference between studentds and teachers preferences.

As the results of the study suggest, while students prefere that teachers give feed back on students' works to the whole class or at least to small groups, teachers are not willing to do so. Interview results suggest that for teachers this is a waste of class time, because on the one hand classes are pressed for the time, and on the other hand, a problem in one student's work is not nessassarily be the case with many others. Students, however, say that although teacher's feedback may not directly point to some students problems, mere repetition of the points raised prevents repeating them in students future works.

\subsection{Testing and evaluation}

One other area that the questionnaire covered was testing and evaluation. According to the results showed in table 4.5, in this analysis, students showed interest in attendnding intensive exam preparation courses; this was not, however, teachers preference, and thus not performed.

None of the parties involved prefered analysing and practicing exam questions in a long-term course or class or workshop. Regarding testing and evaluation, another item that was considered was whether students and teachers prefere formal or informal assessment. in this case, results as well as statistical analysis show significant difference between what students liked, and what teachers prefered.

While students prefered to be evaluated along the program, whether through formal or informal assessment, teachers prefered to evaluate students through formal, traditional mid-term and final exams rather than along the semester through class participation and performance. This may be because the teachers who teach general English courses and participated in this study were mostly visiting teachers and they were busy outside the university. Thses teachers said in the interview that they prefered to use their oun regular multiple choice tests which are easier to administer and score. Interview results also suggest that students, unlike their teachers, prefered to be evaluated through class participation and performance as well as quizes along the semester. Students believed that they score higher through assessments.

\subsection{Participation mode}

Participation mode was one other area covered in this study; an area in which students and teachers showed considerable agreement. Twenty items of the questionnaire explored participation mode and questioned different types of classroom activities. Out of the twenty items, regarding twelve items there was no significant difference between what students and teachers preferred to do in the classroom.

As the results indicate, despite students' interest in library research and independent information finding, teachers prefer to take part in the task to observe and supervise students' attempts. Also, unlike teachers, students' preferred working in pairs, playing roles and doing language games. In addition, while teachers prefer to work with medium and large student groups consisting of ten students or more, students like to work in small groups (maximum five students) especially when it comes to performing writing tasks.

Despite the differences mentioned above, in many cases, students shared the participation mode they preferred with their teachers; for instance, both groups disliked working independently, and preferred group works. As the results suggest, both groups liked reading aloud in the classroom, and oral exercises such as oral presentations and taking part in group discussions. Likewise, both students and teachers were very willing to use language lab. This was because both groups liked audio-visual tasks such as listening to audio recordings and using training videos especially in a way that every student can watch a video individually. Finally, an achievement test is what both groups of the participants like to evaluate students' learning at the end of each session.

\subsection{Class size}

The last area explored in this study was the class size. This part of the questionnaire considered three class sizes; namely, classes with fifteen to twenty students, classes with twenty one to thirty students, and classes with more than thirty students. Classes with a population less than fifteen students were not included in this study because they were not considered normal for General English course in Iran.

According to the results, neither teachers nor students liked working in populated classes with more than thirty students. Results also suggest that while students preferred classes with twenty one to thirty students, teachers were indifferent towards the class size when classes consisted of a population between fifteen to thirty students. Statistical analysis of the results, however, shows no significant difference between students' and teachers' preferred class size. It means that both groups prefer classes with fifteen one to thirty students.

To obtain the required data, this study used a questionnaire which consisted of forty eight items including five areas such as language skills $(\mathrm{N}=15)$, feedback $(\mathrm{N}=6)$, testing and evaluation $(\mathrm{N}=4)$, participation mode $(\mathrm{N}=20)$, and class size $(\mathrm{N}=3)$.

Although the comparison of Lickert scores for each item shows differences between students' and teachers' activity preferences, statistical analysis of the data (Independent samples t-test) showed that only 43.75\%; namely, twenty one out of forty eight of the differences were significant at 0.05 or below. The number of significant differences in each area included nine out of fifteen items for language skills, two out of six items for feedback, three out of four items for testing and evaluation, and seven out of twenty for participation mode. Regarding the class size there was no significant difference. 


\section{Summary And Conclusions}

In order to have an effective second language education, students and teachers should share beliefs and assumptions about language and learning as well as educational goals. Achieving such efficiency requires deep understanding of students' and teachers' beliefs, and considering them in the process of syllabus design and materials preparation for English courses. Teachers of English as a second/foreign language at universities should be aware of their students' beliefs about language and learning as well as their goals, and adjust them with those of the course syllabus and the program in order to be able to teach more effectively.

To provide a deeper understanding of Iranian students' preferences regarding language classroom activities, this research tried to find the participants' preferences and expectations in foreign language learning and teaching through finding out whether there is any correspondence between teachers' and learners' preferred activities, and to what extent teachers' beliefs about language learning and class activities correspond with those of the learners'.

This study consisted of two groups of participants from seven universities. These groups consisted of 28 teachers and 261 students. To obtain the required data, this study made use of a 48 item questionnaire that covered areas such as language skills, feedback, testing and evaluation, participation mode, and class size.

\subsection{Conclusions}

The data obtained were statistically analysed through independent samples t-test. This analysis showed that only $43.75 \%$ (21 out of 48) of the differences were significant at 0.05 or below. The number of significant differences in each area included nine out of fifteen items for language skills, two out of six items for feedback, three out of four items for testing and evaluation, and seven out of twenty for participation mode. The two groups of participants shared preferences regarding the class size.

These findings indicate a need to take more time to share ideas with students regarding classroom practices. This need is more critical when it comes to listening and speaking skills, and especially writing skills. In some cases students prefer an activity only because it is less stressful while it might be less effective as well. However, more research is necessary to find out whether what students prefer, or what teachers do is more effective or if there is any difference.

\section{References}

Allwright, D. (1984). Why don't learners learn what teachers teach? The interaction hypothesis. In D. M. Singleton \& D. G. Little (Eds.), Language learning in formal and informal contexts (pp. 3-18).

Davies, A. (2006). What do learners really want from their EFL course? ELT journal, 60(1), 3-12.

Eslami-Rasekh, Z., \& Valizadeh, K. (2004). Classroom activities viewed from different perspectives: Learners' voice and teachers' voice. TESL-EJ, 8(3), 1-13.

Gabillon, Z. (2005). L2 Learner's Beliefs: An Overview. Journal of Language and Learning, 3(2), 233-260.

Green, J. M. (1993). Student Attitudes Toward Communicative and Non-Communicative Activities: Do Enjoyment and Effectiveness Go Together? The Modern Language Journal, 77(1), 1-10.

Hawkey, R. (2006). Teacher and learner perceptions of language learning activity. ELT journal, 60(3), 242-252.

Kehrwald, J. (2007). Conflicting Voices from the Classroom: Exploring Mismatches Between Language Learners' Beliefs and Curricula Goals. Paper presented at the Exploring Theory, Enhancing Practice: Autonomy Across the Deciplines, Kanda University of International Studies, Chiba, Japan.

Meskill, C. , \& Rangelova, K. (2000). Relocating the 'cognitive' in sociocognitive views of second language learning. In R. Rapp. (Ed.), Linguistics on the Way into the New Millennium: Proceedings of the 34thColloquium of Linguistics. London: Peter Lang-Verlag Publishing.

Nation, I., Stephen, P., \& Macalister, J. (2010). Language curriculum design. New York: Routledge.

Noora, A. (2008). Iranian undergraduates non-English majors' language learning preferences. GEMA: Online Journal of Language Studies, 8(2), 33-44.

Nunan, D. (1995). Closing the gap between learning and instruction. Tesol Quarterly, 29(1), 133-158.

Nunan, D. (1999). Second Language Teaching \& Learning. Boston: Heinle \& Heinle Publishers.

Peacock, M. (1997). Comparing Learner and Teacher views on the Usefulness and Enjoyableness of Materials. International Journal of Applied Linguistics, 7(2), 183-200.

Peacock, M. (1998). Exploring the gap between teachers' and learners' beliefs about 'useful'activities for EFL. International Journal of Applied Linguistics, 8(2), 233-248.

Peacock, M. (1999). Beliefs about language learning and their relationship to proficiency. International Journal of Applied Linguistics, 9(2), 247-263.

Richards, J. C., \& Schmidt, R. (2002). Longman dictionary of language teaching and applied linguistics (3 ed.). London: Longman

Riley, P. A. (2009). Shifts in beliefs about second language learning. RELC Journal, 40(1), 102-124. 
Savage, W., \& Storer, G. (1992). An emergent language program framework: Actively involving learners in needs analysis. System, 20(2), 187-199.

Shahini, A. , \& Daftarifard, P. . (2011). Learners' Beliefs of an Effective Teacher: A Case of Iranian Context. Brain. Broad Research in Artificial Intelligence and Neuroscience, 2(1), 29-37.

Spratt, M. (1999). How good are we at knowing what learners like? System, 27(2), 141-155.

Spratt, M. (2001). The value of finding out what classroom activities students like. RELC Journal, 32(2), 80-101.

Toussi, M. (1998). Attitude, Motivation, and Language attainment in the English as Foreign Language(EFL) Classes: Socio-political and Psychological study of Iranian College Level Students. Department of English. M.A. thesis. Punjab University. India.

Yang, N. (1999). The relationship between EFL learners' beliefs and learning strategy use. System, 27(4), 515-535. 